\title{
Professional competences scale for police officers: evidence of psychometric adequacy
}

\author{
Thiago Gomes Nascimento ${ }^{1}$
}

Eda Castro Lucas de Souza ${ }^{1}$

Breno Giovanni Adaid-Castro 1

${ }^{1}$ Centro Universitário IESB / Mestrado Profissional em Gestão Estratégica de Organizações, Braślia / DF - Brazil

\begin{abstract}
This research evaluated the factorial structure and psychometric adequacy of a Professional Competences Scale for Police Officers (ECPP). The development of the scale was carried out in three steps, with the participation of police officers and university professors holding $\mathrm{PhDs}$ in psychology and administration. The study applied a questionnaire to a non-probabilistic sample of 916 state police officers. The exploratory and confirmatory factorial analyses pointed to a bi-dimensional structure of 16 items. The first factor (behavioral competencies) regards aspects that involve complex relationships between skills related to the individual and attitudes. The second (technical competencies) refers to the knowledge and skills necessary for the good performance of activities in the police service. The results support the structure and point to internal consistency and adequate psychometric validity.

Keywords: performance competence; competencies; scale; police; validity.
\end{abstract}

\section{Escala de competências profissionais para policiais: evidências de sua adequação psicométrica}

Esta pesquisa avaliou a estrutura fatorial e a adequação psicométrica da Escala de Competências Profissionais para Policiais (ECPP). Após o desenvolvimento do instrumento de medida, realizado em três etapas junto a policiais e doutores dos campos de psicologia e administração, realizou-se uma etapa quantitativa com amostra de 916 policiais militares. As análises fatoriais exploratórias e confirmatórias apontaram uma estrutura bidimensional de 16 itens. O primeiro fator (competências comportamentais) está relacionado a aspectos que envolvem relações complexas entre habilidades relativas ao indivíduo e atitudes enquanto o segundo (competências técnicas) se refere a conhecimentos e habilidades necessários para o bom desempenho de atividades no serviço policial. Os resultados suportam a estrutura e apontam consistência interna e validade psicométrica adequada.

Palavras-chave: desempenho competente; competências; instrumento de medida; polícia; validade.

\section{Escala de competencias profesionales para policías: evidencias de su adecuación psicométrica}

Esta investigación evaluó la estructura factorial y la adecuación psicométrica de la Escala de Competencias Profesionales para Oficiales de Policía (ECPP). Después de un procedimiento metodológico de tres pasos para desarrollar el instrumento de medición, con la participación de policías y doctores de los campos de psicología y administración, se llevó a cabo un paso cuantitativo con una muestra de 916 policías militares. Los análisis factoriales exploratorios y confirmatorios indicaron una estructura bidimensional de 16 ítems. El primer factor (competencias de comportamiento) se relaciona con aspectos que involucran relaciones complejas entre las habilidades relacionadas con el individuo y las actitudes, mientras que el segundo (competencias técnicas) se refiere al conocimiento y habilidades necesarias para el buen desempeño de las actividades en el servicio policial. Los resultados apoyan la estructura y señalan consistencia interna y validez psicométrica adecuada.

Palabras clave: desempeño competente; competencias; instrumento de medida; policía; validez. 


\section{INTRODUCTION}

In recent years, within the studies on organizational behavior, the notion of competence has reached great prominence due to the interest of researchers and organizations (Brandão, 2009, 2017; Santos, 2012, 2018). Migrating from a discursive to an operative form, competences are now being used to promote transformations in many areas of the organizational environment, including in issues regarding remuneration, performance evaluations, training programs, among others. The impetus in literature about this theme occurred in the 2000s with the emergence of the competency management model, thus providing discussions about the notion of competence, its dimensions, background and implications (Brandão \& Guimarães, 2001; Gonczi, 1999; McLagan, 1997; Nascimento, 2014).

These points indicate a need for research focused on the nature and measure of the professional competence construct, as well as on the relationships between antecedent and consequent variables that are related, above all, to the Brazilian context (Brandão, 2009; Coelho, 2009; Nascimento, 2014; Santos, 2012). Although there are hypotheses and assumptions about this phenomenon developed by administration or psychology theories, empirical studies that present valid, accurate and reliable measures or, in other words, that are psychometrically adequate, are scarce (Brandão, 2009), especially when considering public administration (Santos, 2012, 2014).

In this sector, specifically in Brazilian police institutions (Nascimento, 2014), research in the area of assessment is needed in order to identify the causes and consequences of police behavior, aiming to develop and improve competent performances (Pasquali, Moura, \& Freitas, 2010). In addition, studies about competence assist in making organizational processes viable, such as strategic planning, and in the elaboration of policies and practices for personnel management, that is, training, improvement and performance evaluation (Faiad, Coelho, Caetano, \& Albuquerque, 2012; Nascimento, 2014; Pasquali et al., 2010).

The publication of Decree n⿳ 5,707 (2006) and of Ordinance $n^{\circ} 208$ (2006), of the Brazilian Ministry of Planning, Budget and Management, which required the development of training plans based on necessary competences, stressed the importance of research in this area. Considering that police activity demands a set of complex characteristics that are difficult to measure (Faiad et al., 2012), it may be relevant to develop a measurement instrument capable of identifying the relationship between the necessary competence and the achievement of the police organization's objective.

In order to find studies that dealt with the measurement of competencies in the Brazilian public administration, specifically in the area of professional performance by competence, a literature review was performed, and no researches focused on police organizations were found. Thus, in order to fill this gap, the following research question arose:

- What would be the appropriate measure for the professional competencies construct destined for the police service?

Therefore, the objective of this research was to search for psychometric evidence (validity and internal consistency) of adequacy of the Professional Competences Scale for Police Officers (ECPP), a measurement that portrays competent performance, contributing to fill research gaps on the subject, specifically for the police organization. 


\section{FROM THE NOTION OF COMPETENCE TO COMPETENT PERFORMANCE}

Several authors (Abbad \& Borges-Andrade, 2004; Brandão, 2009; Brandão \& Guimarães, 2001; Carbone, Brandão, Leite, \& Vilhena, 2005; Coelho, 2009; Coelho \& Borges-Andrade, 2011a; Coelho \& Borges-Andrade, 2011b; Nisembaum, 2000; Santos, 2012; among others) have associated competence to the notion of performance, recognizing that the elements that constitute it - knowledge, skills and attitudes (KSAs) - result in professional performance, with clear reflexes on organizational results (Brandão, 2009; Fogaça, Rego, Melo, Armond, \& Coelho, 2018). From these elements, knowledge represents a set of information that is assimilated and structured by individuals, which enables them to understand the world (Durand, 2000). Ability alludes to knowing how to do something, representing the person's ability to positively use the knowledge they hold, establishing the stored knowledge in their memory and using it in an action (Durand, 2000). Finally, attitude can be defined as a subject's predisposition to react (negatively or positively) to a stimulus. Thus, based on the notion of competences, a person's performance would represent a manifestation of their competences, expressed as a result of the behaviors that an individual adopts at work and the given results (Gilbert, 1978).

Authors such as Bitencourt and Barbosa (2004), McLagan (1997) and Ruas, Ghedine, Dutra, Becker, and Dias (2005), among others, claim that even with the possibility of interpreting competence in different ways, two major theoretical frameworks are found (Dutra, 2004). The first, representing a North American perspective (McClelland, 1973), considers competence as a set of qualifications or characteristics that underlie the individual, which enables him or her to perform a job or deal with a situation. The second, representing the French vision, such as Le Boterf (1999) and Zarifian (1999), associates competence not with a set of attributes of the individual, but with their achievements in a certain context, that is, what the individual accomplishes or produces at work (Brandão \& Borges-Andrade, 2007; Dutra, 2004). For Le Boterf (1999), competent action is a combination and a mobilization of resources. Two elements are present in this concept: the subject's necessary capacities for a competent performance; and effective application of these capabilities to deal with any subject in their field.

However, Brandão (2009) stresses that, in recent years, the emphasis has been given to a third integrative framework, which seeks to define competence based on the connection of the aforementioned frameworks. Gonczi (1999) was responsible for defending this position, recognizing that competence associates personal attributes with the context that they are applied in. Therefore, competence is understood as the performance expressed by the individual in a given context, in terms of the behaviors adopted at work and the resulting achievements, and not just a set of KSAs (Carbone et al., 2005).

These definitions enable the association between competence and performance, either in the academic or the organizational environment, connecting them to the scope of an organizational strategy (Carbone et al., 2005). In this line of thought, competences are manifested when individuals act in the face of professional situations they encounter (Zarifian, 1999), adding value (economic or social) to individuals and organizations, contributing to the achievement of organizational strategies and to the dissemination of social recognition about the capacity of the subjects, the teams and the organizations (Brandão \& Guimarães, 2001; Zarifian, 1999). Thus, KSAs, as constitutive elements of competence, add value through work performance (Durand, 2000; Gonczi, 1999). 
Performance is expressed by behaviors that the individual shows at work, as well as by the consequences of such behaviors, in terms of accomplishments and results (Gilbert, 1978). Therefore, professional performance by competencies has value for the subject that produces it and for the organization to which the individual is connected to. Considering this, this performance can be defined as a set of KSAs that the subject uses to accomplish their work plans and that should be related to the profile desired by the organization (Nascimento, 2014). In order to be competent, the performance needs to impact on the individual's work outcomes (micro level) and on the organization through the breadth of individual outcomes (macro level).

\section{COMPETENCY MAPPING AND POLICE PROFESSIONAL COMPETENCIES}

Competency mapping can be established by identifying and operationalizing the individual competencies that exist in the organization (Faiad et al., 2012). Therefore, it begins from the description of observable behaviors at work, through which it is possible to identify gaps between the necessary competencies to achieve the organizational objectives and the actual existing competences. This identification can aid in the decision-making process, regarding the development and recruitment of professionals, as well as the search for alliances and partnerships that are congruent with the organizational results (Brandão, 2017; Faiad et al., 2012; Glória, Zouain, \& Almeida, 2014).

From the identification and mapping of competences, Faiad et al. (2012) recommend that a profile be defined by the set of competences required for the position, considering the gathered information. Professional studies, for example, include the tasks performed, the necessary requirements to execute them, as well as the working conditions that can facilitate or hinder their performance (National Secretariat of Public Security [Senasp], 2012). The resulting profile can be supported by the KSAs, either alone or in combination, based on established research parameters that express these competencies, which may be technical (job-specific knowledge and skills) and behavioral competencies (BCs) (involving complex relationships between individual skills and attitudes), as pointed out by Faiad et al. (2012). Thus, the measurement of technical competencies (TCs) and BCs in the police work environment enables the description and identification of certain objective, tangible and observable behaviors. This fact allows the construction of management policies and practices, focused on actions of planning, evaluation, monitoring, supervision and redesign of work in the corporation (Brandão, 2017; Faiad et al., 2012; Nascimento, 2014).

Competences focused on the professional activity of police officers, has been a recurring theme in recent years (Cordeiro \& Muniz, 2010). In this sense, Nascimento (2014, p. 23), associating police service with the notion of competence, defines this service as "a set of technical and behavioral attributes necessary for the fulfillment of the constitutional functions of the police".

From this premise, in order to develop their activities, policemen need a set of peculiar characteristics, which can be expressed in terms of competencies (Faiad et al., 2012). They require SKAs that are directed towards the achievement of different objectives of police actions, which encompass aspects related to coping with crime (e.g., legal and sociopsychological), including mediation and conflict resolution and, finally, the use of force (Veiga \& Souza, 2018). In addition to these competences there is a need for policemen to have characteristics that are considered performance facilitators, such as: level of aggressiveness; specific abilities; intelligence (Faiad et al., 2012). 
In the case of this article, which presents the State Police (Gendarme) as a locus, the chosen activity for the study, among other aspects, refers to preventive policing, when there is a possibility of disturbance of public order, and to its repressive aspect, when there is a break of public order, with staggered use of force.

Examples of the use of professional police competencies, which involve the separation of technical and behavioral aspects, can be found in various works. For instance, the studies by Morrissom and Vila (1988) and by Marion (1998) on the qualification of police officers to use firearms. Their results showed that the abilities (technical and behavioral) acquired at the police academies were adequate but not appropriate for tactics and decision making. On the other hand, studies by Yang, Yen and Chiang (2012) indicate that leadership competencies, in terms of intellectual, managerial, emotional and social competence, are associated with the team members' work satisfaction regarding growth, personal development, human supervision relationships, opportunities for progress and compensation.

In 2012, the National Secretariat of Public Security (Senasp) conducted a large survey $(15,822$ gendarme police officers), with the objective of determining the psychological requirements necessary for the proper development of the tasks related to the mission of the Gendarme Police. This effort allowed a previous mapping of the necessary competencies to execute the tasks, focusing on KSs (knowledge and skills) and on BCs (attitudes).

To assess the professional profile, Senasp (2012) organized focus groups, each with 10 gendarme police officers of different hierarchical levels and with different expertise and job descriptions. The participants were selected according to their good performance, experience, knowledge and mastery of their job activities (Senasp, 2012). Each focus group met for 3 days and were each responsible for gathering and debating the necessary information in order to perform the professional profiling and subsequent competency mapping. The predicted goals for the focus groups were: a) survey the agencies' mission; b) survey the tasks related to the missions; c) categorize the tasks; d) survey the facilitators and hinders of the tasks; e) survey the restrictive psychological requirements necessary for the proper performance of each task; and f) build a professional profile record of each position (Senasp, 2012). Following the focus groups' collection of information, centering on the TCs (knowledge and abilities) and BCs (attitudes), the competency mapping instrument was built.

It is worth noting that the competency mapping carried out in the survey conducted by Senasp (2012) relied on different TCs and BCs that could refer to specific hierarchical levels, not being common to all. However, it could serve as a basis for the construction of a more parsimonious measurement instrument that could be used by any police institution, in its various positions.

In another study, Glória et al. (2014) described the TCs and skills required for a federal criminal expert, acting as the head of the Federal Police's forensics unit. According to the authors, the research results present some TCs and skills considered more relevant, as well as the competence gaps that need to be developed for the proper performance of the duties. In addition, they made it possible to improve the understanding of the relationship between competences and skills and to clarify the scenario of advances and limitations in the Federal Police management.

More recently, the studies by Bäck, Vallès, and Padyab (2017) compared the competencies between police agencies (Catalan and Swedish), with the purpose of knowing how police students perceive the importance of different competences (cognitive competence, functional competence and social 
competence) for the execution of police activities. The results showed that from the beginning to the end of the education and training program, the students (Catalan and Swedish policemen and women) changed their perceptions regarding the importance of the different dimensions of competence for the exercise of police activity. However, other authors point out that the changes were different: for the Swedish, the tendency was for the importance of the different dimensions of competence to decrease throughout the training, while for Catalan police officers the importance of the competence dimensions increased during the education and training program (Bäck et al., 2017).

It is noteworthy, however, that although the professional competence evaluation for police officers has been investigated, the competence measurement instruments used, in most cases, were adapted from other contexts or used to measure general competences, such as the studies presented in this article. In addition, as shown in the review conducted by Aguilar-Moya, Melero-Fuentes, AleixandreBenavent, and Valderrama-Zurián (2013), when compared to international studies, Brazil does not give due importance to professional competence studies or to the development of measurement instruments for these competences.

Although there are initiatives, such as the study by Caetano (2007), on the validation of an inventory of personal competencies for work, which used a sample of police officers, the instrument was built to assess non-specific personal competencies, addressing a set of common competencies to various professions. Therefore, no measurement instruments of competence specific to police officers and that presented TCs and BCs associated to the characteristics of police activity were found, reinforcing the reason for this study.

\section{METHOD}

The first part of the method describes the research's locus, which is the police organization that provided the answered surveys. Then, it describes the development process of the measurement instrument (Phase 1), following to Phase 2, which presents the evidences of validity of the measurement instrument, defining the participants and the procedures of data collection and analysis.

\subsection{Describing the state police profession}

This research was developed within the Federal District Satate Police (PMDF), characterized as a permanent institution, based on the principles of hierarchy and discipline, essential to the public security of this federative unit. The PMDF is the Army's auxiliary and reserve force in cases of summoning or mobilization. It is organized and maintained by the Brazilian Federal Government under the terms of the Constitution of the Federative Republic of Brazil (1988), item XIV of Article 21 and paragraphs 5 and 6 of Article 144. "Subordinate to the Governor of the Federal District, [PMDF is destined] for overt policing and the preservation of public order in the Federal District" (Law No. 12,086 of 2009).

Police service, as well as the gendarme police profession, are presented and discussed by several authors, such as Nascimento (2014), Rodrigues, Nascimento, and Neiva (2014) and Nascimento and Souza (2017), clarifying the peculiar nature of the state police activity because of its capacity to use coercion, that is, peaceful alternatives of obedience backed by force, under social consent 
and before the rule of law (Muniz \& Proença Junior, 2014). In addition, in terms of the performed functions, these actors are associated with the formation of a generalist professional, endowed with a comprehensive, systemic and integrated view of the public security problems. Even though the gendarme police profession presents contradictions regarding its insertion into a classic management organization (Nascimento, 2014), these individuals need autonomy, creativity, situational awareness, quick decision-making, self-control, as well as physical and psychological abilities to deal with the various everyday situations (Nascimento \& Souza, 2017).

In this sense, the duties of the gendarme police can be assessed in terms of TCs, defined by knowledge and skills, directed and applied to the responsibilities, tasks, attributions and duties particular to the positions and roles, that is, "to know" and "to know how" are essential to the execution of their tasks (Faiad et al., 2012; Glória et al., 2014; Nascimento, 2014). The TCs, as the authors point out, consider skills and attitudes compatible with the attributions that must be performed in a given position, regarding to "wanting to do", fundamental to the competent performance of the position or role.

\subsection{Phase 1: The development of a Professional Competence Measure for Police Officers}

In this study, the survey conducted by Senasp (2012) was used, being considered for the construction of the items the theoretical and methodological recommendations and the practical implications presented by Faiad et al. (2012), stemming from the application of professional profile analysis and mapping of competences within police institutions. In addition, the recommendations by Pasquali (2010) were taken into consideration for the construction of the measurement instrument.

Therefore, in this study, the choice of items that composed the ECPP was made by judges, 20 gendarme police officers (from different hierarchical levels), who analyzed a set of competencies from a list of 102 TCs and 36 BCs from the Senasp research (2012). These police officers chose a set of competencies (technical and behavioral), having relevance as a criterion, the importance of the task (high importance for the professional activity) and its representation of all the hierarchical levels of the Gendarme Police, that is, from soldier to colonel. Therefore, competence, be it technical or behavioral, should be able to be used to assess different positions of the police hierarchy, from the lowest level (soldier) to the highest (colonel). Consequently, the large exclusion of items is justified, only retaining those that were common to all levels of the organization.

Having done that, we proceeded to the next step in the validation of the judges, carried out with experts in the area of competencies construct at work and in organizations. The items were evaluated regarding their adequacy of behavioral representation of the latent attributes, as well as those regarding criteria of clarity and objectivity, among others recommended by Brandão and Bahry (2005) and Pasquali (2010). At this point, $8 \mathrm{PhD}$ professors in psychology or administration were consulted, which is a number higher than the recommended by Pasquali (2010). An $80 \%$ agreement among the judges was adopted to define the pertinence of the item (Pasquali, 2010), that is, the item was maintained if it reached this acceptance limit among the judges.

The result of the judge analysis culminated in the selection of 29 items, 13 of which related to TCs and 16 to BCs. These items went through the semantic validation (Pasquali, 2010) of a group composed of 10 members of the target population, with the objective of verifying is they were 
intelligible to gendarme police, making it possible to identify flaws, overcome ambiguities and ensure the comprehension of the items and of the scale by the surveyed population. Box 1 summarizes steps followed.

BOX 1

\section{STEP-BY-STEP OF THE DEVELOPMENT OF THE PROFESSIONAL COMPETENCES SCALE FOR POLICE OFFICERS}

\begin{tabular}{|c|c|c|}
\hline N & Steps & Description \\
\hline 1 & $\begin{array}{l}\text { Analysis of the set of competences of the Senasp } \\
\text { study (2012) }\end{array}$ & $\begin{array}{l}20 \text { police officers (different hierarchical levels) selected the } \\
\text { technical and the behavioral competencies that presented } \\
\text { pertinence, importance and representativeness, that is, that } \\
\text { were common to all hierarchical levels of the police. }\end{array}$ \\
\hline 2 & Judge Analysis (Construct Analysis) & $\begin{array}{l}8 \mathrm{PhD} \text { professors in administration or psychology verified } \\
\text { the adequacy of the latent attributes of measurement, clarity } \\
\text { and objectivity, proposing, as appropriate, the necessary } \\
\text { adjustments. } 80 \% \text { of the judges are expected to associate } \\
\text { the items with the corresponding factors. }\end{array}$ \\
\hline 3 & Semantic Analysis & $\begin{array}{l}10 \text { police officers (from different hierarchical levels) checked } \\
\text { the intelligibility of the items as a means of determining } \\
\text { their apparent validity, and proposed adjustments and } \\
\text { modifications to the instrument when necessary. }\end{array}$ \\
\hline
\end{tabular}

Source: Elaborated by the authors.

\subsection{Phase 2: Gathering evidence of validity of the Professional Competence Measure for Police Officers}

\subsubsection{Research Participants}

This research, which aimed to verify evidence of factorial validity and internal consistency of the ECPP, used a total sample of 916 gendarme police officers, predominantly male $(88.35 \%)$ and highly educated (56.2\% college graduates and $26.4 \%$ postgraduates). Police officers from all hierarchical levels of the corporation participated in survey, ranging in age from 24 to 53 years $(\mathrm{M}=39.02$ e $\mathrm{SD}=6.91)$, who, on average, presented 16.18 years of service $(\mathrm{SD}=8.49)$, most of them married (64.1\%) and Catholic (49.45\%), with an average of 1.64 children $(\mathrm{SD}=1.28 \%)$. Of this total, 9.5\% were soldiers $\left(\mathrm{N}_{\text {population }}=14.93 \%\right), 20.31 \%$ were corporals $\left(\mathrm{N}_{\text {population }}=21.59 \%\right)$ $12.45 \%$ were $3^{\text {rd }}$ sergeants $\left(\mathrm{N}_{\text {population }}=19.41 \%\right), 8.41 \%$ were $2^{\text {nd }}$ sergeants $\left(\mathrm{N}_{\text {population }}=15.01\right)$, $13.43 \%$ were $1^{\text {st }}$ sergeants $\left(\mathrm{N}_{\text {population }}=15.48 \%\right), 5.35 \%$ were lieutenants $\left(\mathrm{N}_{\text {population }}=4.32 \%\right), 8.30 \%$ were cadets $\left(\mathrm{N}_{\text {population }}=0.34 \%\right), 5.35 \%$ were aspiring officers $\left(\mathrm{N}_{\text {population }}=1.19 \%\right), 2.4 \%$ were $2^{\text {nd }}$ lieutenants $\left(\mathrm{N}_{\text {population }}=0.91 \%\right), 2.07 \%$ were $1^{\text {st }}$ lieutenants $\left(\mathrm{N}_{\text {population }}=0.79 \%\right), 5.13 \%$ were captains $\left(\mathrm{N}_{\text {population }}=2.61 \%\right), 3.71 \%$ were majors $\left(\mathrm{N}_{\text {population }}=2.15 \%\right), 1.2 \%$ were lieutenant colonels 
$\left(\mathrm{N}_{\text {population }}=0.84 \%\right)$ and $0.87 \%$ were colonels $\left(\mathrm{N}_{\text {population }}=0.43 \%\right)$, and $14(1.53 \%)$ did not respond. Since the sample did not respect the law of large numbers, it was considered non-probabilistic, restricting the participation to people who agreed to collaborate with the research.

\subsection{Measurement Instruments}

The participants answered a two-part questionnaire:

- The ECPP, with 29 items distributed in 2 dimensions corresponding to the proposed theoretical factors, namely: a) TCs (e.g. ability of using weapons and ammunitions when necessary); and b) BCs (e.g. capacity to act proactively - seeking solutions to problems demonstrating determination). The items were answered on a Likert scale, in terms of mastery (their own expertise), varying from 1 (I have no mastery of the competence - I don't have the competence) to 5 (I have complete mastery of the competence - excellence in the competence);

- Finally, in order to characterize the study participants, a set of sociodemographic questions (education, gender, age, marital status, religion, hierarchical level and length of service) was added.

\subsection{Procedures}

The application of the questionnaires was done in person, ensuring the anonymity and confidentiality of the answers, as explained in the Free and Informed Consent Form (FICF). They were applied in the participant's workplace, in an appropriate location, to ensure minimal interference. On average, 15 minutes were enough for the completion of the survey.

\section{PRELIMINARY ANALYZES}

Before carrying out the analyzes to evaluate the evidence of exploratory and confirmatory validity of the ECPP, this study sought to verify if the respondents considered competencies, whether technical or behavioral, important for the performance of their functions. The importance (of competence to professional activity) was measured using a Likert scale, varying as follows: 1 (no importance - irrelevant competence); 2 (minor importance); 3 (medium importance); 4 (high importance necessary competence); and 5 (extreme importance - indispensable competence). The average of the 916 respondents was 4.44 ( $\mathrm{SD}=0.69)$. This result guarantees that the ECPP, which measures the level of competence mastering, represents competences deemed of high or extreme importance for the entire research sample, showing that its application can be performed with professionals of all levels of the organization, with the same importance, on average.

\subsection{Exploratory factor analysis}

With the specific goal of gathering evidences about the factorial validity and internal consistency of the ECPP, measure that represents the competent performance itself. In this study, latent constructs that can explain the covariance between the items were highlighted, the specific variances (i.e. individual portions of the items) that did not covariate with each other were not considered 
(Damásio, 2012). The study was based on a preliminary analysis of this measure, checking the suitability for a two-factor structure to represent the competence construct through its two dimensions: TCs; and BCs.

Since it is not recommended that exploratory and confirmatory analysis be performed with the same set of data (Marôco, 2011), after the adjustments to complete the multivariate analysis, the total sample $(\mathrm{n}=916)$ was randomly divided into two subsamples, using the standard database divisor of the SPSS Statistics Software (version 20), as recommended by the mentioned author. Therefore, $50.11 \%$ of the respondents were selected for an exploratory phase $(n=459)$. In this phase of the research, the sample consisted of 459 gendarme police officers of the Federal District, mostly male $(90.9 \%)$ and with high education (56.5\% college graduates and $26.4 \%$ postgraduates). Police officers from all hierarchical levels of the Corporation participated, ranging in age from 24 to 53 yeas $(\mathrm{M}=39.01$ and $\mathrm{SD}=6.86)$, who on average had 16.15 years of service $(\mathrm{SD}=8.44)$, mostly married (62.4\%) and Catholic (51.6\%).

For the confirmatory phase of the research, the sample included 457 gendarme police officers of the Federal District, mostly males (88.1\%) and with high education (56.4\% college graduates and $23.3 \%$ postgraduates). Police officers from all hierarchical levels of the Corporation participated, ranging in age from 25 to 53 years $(M=39.01$ and $S D=6.97)$, who on average had 16.21 years of service (SD $=8.55)$, mostly married (67.6\%) and Catholic (49.9\%).

The SPSS Statistics software (version 20) was used to perform the exploratory analyzes, which allowed the calculation of the correlation coefficients between the items, as well as the evaluation of the corresponding matrix adequacy indicators (KMO and Bartlett's Sphericity Test) for the accomplishment of the factor analysis. In this same statistical software, the principal component analysis was performed, which made it possible to verify the existence or not of anomalous samples, the relationships between the measured variables and the connections or groupings between samples. The internal consistency (Cronbach's alpha) for the resulting components was also calculated.

The ECPP was operationalized based on the method proposed by Faiad et al. (2012) for professional and competence mapping in police institutions, considering the mapping of gendarme police competencies performed (Senasp, 2012), in which the TCs and BCs of the gendarme police officers were taken into account, being measured in terms of competence mastering, based on the competences considered of major importance.

In this first part of phase 2, the study sought to find evidence of factorial validity and internal consistency of the ECPP, performing exploratory analyzes to check the number and the adequacy of the factors to be extracted.

\subsubsection{Gathering Evidence of Exploratory Validity of the Professional Competences Scale for Police Officers}

The ECPP items presented averages ranging from 3.55 ( $\mathrm{SD}=0.77$; Item 2. Being able to act demonstrating knowledge of legislation, rules and internal regiments applied to the gendarme police function) to 4.44 ( $\mathrm{SD}=0.72$; Item 9 . Ability to use personal and professional experience when planning actions, following relevant rules, doctrine and legislations within the scope of the PMDF). 
Then, the discriminative power of the items was tested. In order to do that, the empirical median criterion was used to define the criterion groups. The total score of the scale was calculated from the sum of all the items, which allowed the definition of the lower and upper groups, according to the total scores of the participants that were below or above the median. For each item, a t-test was calculated comparing the averages of the two groups. The results of the t-test indicated that all the items presented satisfactory discriminative power $(p<0.000)$. Given these considerations, the study sought evidence of factorial validity and internal consistency of the ECPP.

The ECPP structure was verified by assessing the adequacy of performing a factor analysis with favorable results: $\mathrm{KMO}=0.96$ and Bartlett's Sphericity Test $\mathrm{X}^{2}(406)=7153.59, p<0.000$. Therefore, a preliminary principal component analysis (PCA) was performed, without setting the number of factors to be extracted or the type of extraction. Together with these results, the intercorrelation matrix demonstrated that it was possible to perform the factorization of the ECPP.

Then, the dimensionality of the scale was analyzed based on different methods. The Kaiser criterion identified up to 3 factors that explain $54.88 \%$ of the total variance. The first factor is the determinant ( $\Delta$ between the first and the third factors is $38.58 \%$ ). The scree plot test indicated that the ECPP presents up to 3 components. However, given the fragility of these criteria, Horn's parallel analysis was performed, considering a confidence of $99 \%$ and 1,000 databases that simulated this research, that is, 459 participants and 29 items. From the results of the eigenvalues and the simulated eigenvalues, it was noticed that the third eigenvalue resulting from the PCA (1.142) was lower than the simulated eigenvalue (1.389), indicating the presence of 2 factors. Since parallel analysis has been considered a technique of greater precision for the number of factors (Laros, 2012), a bifactor solution was chosen.

From this information, the study proceeded to a factor analysis using the main axis method, with promax rotation, for the extraction of 2 factors. Items 9,10 and 12 (regarding TCs) and items 1 and 4 (regarding BCs) were excluded, because these items do not saturate in the corresponding theoretical factors. Items 11 and 13 (TCs) and items 2, 3 and 5 (BCs), which saturated in more than one factor and whose differences was less than 0.1 , were excluded. The new analysis improved the representativeness of the items that now explained 53.52\% of the total variance. The final structure of the ECPP, however, retained 19 items that presented theoretical compatibilities and parsimony. Table 1 summarizes the retained results of the exploratory factor analysis.

TABLE 1 FACTORIAL MATRIX OF THE PROFESSIONAL COMPETENCES SCALE FOR POLICE OFFICERS

\begin{tabular}{lccc} 
Items & Factor 1 & Factor 2 & $\begin{array}{c}\text { Communalities } \\
\left(\mathbf{R}^{2}\right)\end{array}$ \\
BC12 & 0.78 & & 0.64 \\
BC13 & 0.77 & 0.59 & \\
BC15 & 0.75 & 0.59 & \multicolumn{2}{c}{ Continue } \\
\hline
\end{tabular}




\begin{tabular}{|c|c|c|c|}
\hline Items & Factor 1 & Factor 2 & $\begin{array}{c}\text { Communalities } \\
\left(\mathbf{R}^{2}\right)\end{array}$ \\
\hline BC16 & 0.74 & & 0.62 \\
\hline BC10 & 0.72 & & 0.50 \\
\hline BC08 & 0.66 & & 0.50 \\
\hline $\mathrm{BCO7}$ & 0.63 & & 0.54 \\
\hline BC09 & 0.60 & & 0.53 \\
\hline BC11 & 0.50 & & 0.49 \\
\hline BC14 & 0.49 & & 0.44 \\
\hline BC06 & 0.46 & & 0.46 \\
\hline TCO4 & 0.81 & & 0.62 \\
\hline TCO3 & 0.81 & & 0.62 \\
\hline TC02 & 0.75 & & 0.63 \\
\hline TCO7 & 0.68 & & 0.60 \\
\hline TC 01 & 0.67 & & 0.55 \\
\hline TC 08 & 0.66 & & 0.59 \\
\hline TC 06 & 0.62 & & 0.54 \\
\hline TC 05 & 0.61 & & 0.46 \\
\hline Number of items & 11 & 8 & \\
\hline Eigenvalue & 7.92 & 2.24 & \\
\hline \% explained var. & 41.71 & 11.81 & \\
\hline Alpha & 0.90 & 0.89 & \\
\hline Lambda 2 & 0.91 & 0.89 & \\
\hline Load average & 0.65 & 0.70 & \\
\hline
\end{tabular}

Source: Elaborated by the authors.

Note: $\mathrm{TC}=$ technical competence; $\mathrm{BC}=$ behavioral competence.

The first ECPP factor was formed by items concerning TCs, which regarded social abilities and professional attitudes when dealing with people and everyday situations. Influenced by organizational culture, its development is stimulated by individual characteristics, such as curiosity, caution, boldness, reason, among others (Nascimento, 2014). The second factor, TCs, is based on the knowledge and abilities acquired during the individual's professional development and in their specialization and continued training throughout their career, being part of the individual's curriculum and needing to be adequate to their performed duties (Nascimento, 2014). Together, the factors justified $53.52 \%$ of the explained variance. Regarding accuracy, calculated by Cronbach's alpha and Guttman's lambda 2, the factors presented very good indices.

Finally, the correlation between the items of the two ECPP factors were calculated. The first factor, BCs, presented positive correlation between the items ranging from 0.29 to 0.65 ( $_{\text {mean }}=$ 
0.47); the second factor, TCs, presented positive correlation between items ranging from 0.39 to $0.60\left(\mathrm{r}_{\text {mean }}=0.51\right)$.

The procedures to perform the confirmatory factor analysis (CFA) are presented below as a way of ratifying the structure obtained with exploratory factor analysis (EFA).

\subsection{Confirmatory factor analysis}

This final phase seeks to explore the previous one, contributing to the confirmatory procedures to check for the adequacy of the ECPP. In a concrete way, the objective was to test the factorial structure of this measure, verifying its discriminant and convergent validity as well as the stability of its internal consistency (Cronbach's alpha and Rho Jöreskog). It is important to highlight that CFA is a statistical technique used to evaluate the adjustment quality of a theoretical measurement model to the correlational structure observed between the manifest variables (Marôco, 2011). It can be understood as an extension of EFA, but one that represents some differences, above all the strong dependence of EFA on matrix R, while CFA imposes on the data (matrix R) a preliminary theoretical structure, as well as the need to adapt the empirical data expressed by the same matrix R (Pasquali, 2012).

The participants answered the ECPP and followed the same collection procedures as in the exploratory phase, maintaining the response scale, as well as the same demographic questions previously listed. The maintenance of the 29 items of the exploratory study is justified as the CFA cannot confirm the factorial structure obtained with EFA, for example, when considering the difference in the extraction of factors, Kaiser criterion and percentage of variance explained, main components method versus maximum likelihood of CFA (Marôco, 2014).

The ECPP factorial structure was verified using the AMOS 18 software. To perform the CFA, the covariance matrix was considered as input and the ML (Maximum Likelihood) estimator was adopted. This statistical analysis is considered more rigorous than the employed PCA criterion, since it allows the direct testing of a theoretical structure. As a way of confirming the existing latent structure, the relationships between the variables were specified, taking into consideration the adjustment indices to decide if the data fit the model. In case of satisfactory indices, it was concluded that the model fits the data. Therefore, absolute and relative indices were used, as well as indices of populational discrepancy and parsimony and information-theory-based indices, with their respective reference values (for more details see Marôco, 2011; Nascimento, 2014; Roussel, Durrieu, Campoy, \& Akremi, 2002), described in Table 2.

This phase sought to test the two-factor model found in the exploratory analysis, for which a CFA was performed assuming that the set of items saturates in two correlated factors.

\subsubsection{Gathering evidence of confirmatory validity of the Professional Competences Scale for Police Officers}

In this stage, 3 models were analyzed in order to evaluate the quality of the data adjustment to the proposed model. The first evaluated a one-dimensional model (Harman test, according to Malhotra, Kim, \& Patil, 2006). The second, a model with 2 factors originating from EFA, and a model with the presence of 1 second-order factor, justified by the 0.60 correlation between the EFA factors (Roussel et al., 2002). 
Model 1 (one-dimensional) did not present satisfactory adjustments, which led to its rejection, reinforcing studies that show that the competence construct is multidimensional. Model 2 presented satisfactory adjustment indices after the elimination of items that presented standardized residual covariance higher than the limit of $|2.58|$, according to MacCallum (1986), whose modification indices were inadequate, when saturating, with higher values (> 11, according to Marôco, 2011), in more than one item. Therefore, items 11 (BC11, 14 (BC14) and 16 (BC16). Moreover, Model 2 presented correlations greater than 0.60 between the factors, which allowed the test of Model 3 with the presence of a second order factor. Model 2 (2 dimensions of order 1) presented the same adjustment indices as Model 3. In this case, Model 3 was preferred, which considers the second-order factor, as observed by Roussel et al. (2002), namely, the factor that contains the dependent dimension to be measured, that is, professional competences that represent the competent performance itself (Nascimento, 2014) which can be observed in Table 2 .

\section{TABLE 2 ADJUSTMENT INDICES OF MEASUREMENT MODELS ACCORDING TO MODELS 1, 2 AND 3 OF THE PROFESSIONAL COMPETENCES SCALE FOR POLICE OFFICERS}

\begin{tabular}{|c|c|c|c|c|c|}
\hline $\begin{array}{l}\text { Sample } \\
n=451\end{array}$ & Reference values & & $\begin{array}{l}\text { Model } 1 \text { one- } \\
\text { dimensional }\end{array}$ & $\begin{array}{c}\text { Model } 2 \\
2 \text { dimensions }\end{array}$ & $\begin{array}{l}\text { Model } 3 \\
2^{\text {nd }} \text { order }\end{array}$ \\
\hline \multirow[t]{3}{*}{ Absolute Indices } & $\left(1 \leq \chi^{2} /\right.$ d.f. $\left.\leq 5\right)$ & $\begin{array}{c}\chi / \text { d.f. } \\
\chi^{2} ; \text { d.f. } \\
p\end{array}$ & $\begin{array}{c}6.08 \\
924.50 ; 152 \\
0.000\end{array}$ & $\begin{array}{c}2.30 \\
237.23 ; 103 \\
0.000\end{array}$ & $\begin{array}{c}2.30 \\
237.23 ; 103 \\
0.000\end{array}$ \\
\hline & $>0.90$ & GFI (AGFI) & $0.76(0.70)$ & $0.94(0.92)$ & $0.94(0.92)$ \\
\hline & $<0.10$ & SRMR & 0.074 & 0.038 & 0.038 \\
\hline \multirow[t]{2}{*}{ Relative Indices } & $>0.90$ & $\mathrm{CFI}$ & 0.82 & 0.96 & 0.96 \\
\hline & $>0.90$ & TLI & 0.80 & 0.96 & 0.95 \\
\hline $\begin{array}{l}\text { Population } \\
\text { discrepancy indices }\end{array}$ & $<0.10$ & $\begin{array}{c}\text { RMSEA } \\
\text { (Lo90;Hi90) }\end{array}$ & $\begin{array}{c}0.106 \\
(0.099 ; 0.112)\end{array}$ & $\begin{array}{c}0.053 \\
(0.045 ; 0.062)\end{array}$ & $\begin{array}{c}0.052 \\
(0.045 ; 0.062)\end{array}$ \\
\hline \multirow[t]{2}{*}{ Parsimony indices } & $>0.60$ & PCFI & 0.72 & 0.82 & 0.82 \\
\hline & $>0.60$ & PGFI & 0.61 & 0.71 & 0.71 \\
\hline \multirow{3}{*}{$\begin{array}{l}\text { Indices based on } \\
\text { Information Theory }\end{array}$} & Lower value & AIC & 1038.50 & 303.23 & 303.23 \\
\hline & Lower value & ECVI & 2.28 & 0.66 & 0.66 \\
\hline & & CAIC & 1195.24 & 472.35 & 472.35 \\
\hline
\end{tabular}

Source: Elaborated by the authors. 
All items of the ECPP presented saturation (factor weights, $\lambda$ ) statistically different from zero $(\lambda \neq 0 ; \lambda>0.5 ; z>1.96, p<0.001)$. Therefore, there seems to be evidence of this measure's factorial validity. The final confirmatory factor structure corresponding to Model 2 and Model 3 (second order) can be observed in Table 2.

Once the factorial structure of the ECPP is known, it is necessary to obtain information on its accuracy, assessed by Jöreskog's Rho $(\rho)$. Since the Cronbach's alpha measurement is sensitive to the number of factor items, Jöreskog $\rho$ will be used because it is the part of the variance of compound factors shared by the items that measure this factor. Thus, representing the internal consistency of the reflexive items of the factor, the degree to which these items are manifestations of the latent factor is indicated (Jöreskog, 1971; Marôco, 2011). The Jöreskog Rho value of the ECPP factors presented excellent consistency. Similarly, the convergent validity was satisfied for all the factors, which presented multiple squared correlations greater than 0.50 , providing complementary evidence of convergent validity (Bagozzi \& Yi, 1988). Discriminant validity was tested between dimensions $\left(\mathrm{Rho}_{\mathrm{cv}}>\mathrm{r}^{2}\right)$ and was confirmed in its entirety. Table 3 presents the summary of the psychometric qualities of the ECPP.

\section{TABLE 3}

RELIABILITY AND VALIDITY OF THE DIMENSIONS ACCORDING TO MODEL 2 AND MODEL 3 (SECOND ORDER) OF THE PROFESSIONAL COMPETENCES SCALE FOR POLICE OFFICERS

\begin{tabular}{|c|c|}
\hline Reliability and convergent validity of Model 3 & Factor weights \\
\hline \multicolumn{2}{|l|}{ Professional Competence Dimension: $\rho=0.83 ;$ Rhocv $=0.71, \mathrm{t}>1.96$} \\
\hline Behavioral Competence Dimension $(\mathrm{BC}): \rho=0.89 ;{ }^{* \star} \mathrm{Rhocv}=0.51, \mathrm{t}>1.96$ & 0.83 \\
\hline $\begin{array}{l}\text { BC06_Ability to act empathetically (to understand and put oneself in the other's place understanding one's } \\
\text { feelings and general perceptions/general beliefs). }\end{array}$ & 0.63 \\
\hline BC07_Ability to act with persistency and determination, demonstrating interest and commitment to work. & 0.70 \\
\hline $\begin{array}{l}\text { BC08_Ability to act with flexibility (knowing how to accept suggestions and criticism, as well as adjusting } \\
\text { appropriately to new facts, concepts or situations). }\end{array}$ & 0.74 \\
\hline BC09_Ability to act impartially (acting neutrally and impersonally). & 0.68 \\
\hline $\begin{array}{l}\text { BC10_Ability to act with concern for their own safety (striving for their physical integrity, in a cautious } \\
\text { manner). }\end{array}$ & 0.69 \\
\hline BC12_Ability to act ethically and professionally. & 0.79 \\
\hline BC13_Ability to work in a team. & 0.76 \\
\hline BC15_Ability to act with deference (capacity to abide by and to comply with rules). & 0.72 \\
\hline Technical Competence Dimension (TC): $\rho=0.87 ; \mathrm{Rho}_{\mathrm{cv}}=0.51, \mathrm{t}>1.96$ & 0.85 \\
\hline TC01_Ability to use weapons and ammunition when necessary. & 0.59 \\
\hline
\end{tabular}




\begin{tabular}{|c|c|c|c|}
\hline \multicolumn{3}{|c|}{ Reliability and convergent validity of Model 3} & Factor weights \\
\hline \multicolumn{3}{|c|}{$\begin{array}{l}\text { TC02_Being able to act demonstrating knowledge of legislation, rules and bylaws applied to the police } \\
\text { function. }\end{array}$} & 0.63 \\
\hline \multicolumn{3}{|c|}{$\begin{array}{l}\text { TC03_Ability to identify and manage conflicts (identifying points of divergence and convergence, seeking } \\
\text { appropriate solutions to resolve conflicts). }\end{array}$} & 0.68 \\
\hline \multicolumn{3}{|c|}{$\begin{array}{l}\text { TC04_Ability to have a systemic vision (comprehending the whole in a given situation, being able to } \\
\text { combine coordinated parts that form a set). }\end{array}$} & 0.69 \\
\hline \multicolumn{3}{|c|}{ TC05_Being able to work in an interdisciplinary way. } & 0.69 \\
\hline \multicolumn{3}{|c|}{ TC06_Ability to respond immediately to society, according to its needs. } & 0.75 \\
\hline \multicolumn{3}{|c|}{ TC07_Ability to persuade and argue (power to convince; ability to argue and counter argue). } & 0.71 \\
\hline \multicolumn{3}{|c|}{$\begin{array}{l}\text { TC08_Ability to use personal and professional experience when planning actions, following rules, doctrine } \\
\text { and legislation relevant to the scope of the police organization. }\end{array}$} & 0.71 \\
\hline \multicolumn{4}{|c|}{ ECPP Discriminating Validity * } \\
\hline & $\mathrm{BC}$ & $\mathrm{TC}$ & \\
\hline $\mathrm{BC}$ & 0.512 & & \\
\hline TC & 0.498 & 0.506 & \\
\hline
\end{tabular}

Source: Elaborated by the authors.

* Discriminant validity occurs when the average variance extracted from the factors are greater than or equal to the square of the correlations between these factors.

${ }^{*} \mathrm{Rho}_{\mathrm{cv}}-$ Convergent validity measure.

\section{DISCUSSION AND FINAL CONSIDERATIONS}

This article adapts and gathers psychometric evidences of the adequacy of the ECPP, knowing its factorial validity, convergent and discriminant validity, as well as confirming homogeneity and internal consistency. The operationalization of the professional performance measurement by competences was based on the method proposed by Faiad et al. (2012) for the professional profile and competencies survey in police institutions, and in the of competency mapping (technical and behavioral), performed by Senasp (2012), measured in terms of competence domain, supported by the competences considered of greatest importance.

Several studies have shown the use of competences for measuring work performance (Brandão, 2009; Brandão et al., 2012a, 2012b; Carbone et al., 2005; Santos, 2012, 2018), but none of them were directed to the police public. Therefore, this measure was proposed, based on TCs and BCs, as recommended by Faiad et al. (2012) and Senasp (2012), because they assessed, respectively, knowledge and ability related to the position, as well as distal abilities and attitudes compatible with the attributions to be performed in the position.

The EFA results confirmed the two-dimensionality of the construct, formed by a factor corresponding to the technical competences (TCDs) and another factor covering the behavioral 
competences (BCDs). The ECPP retained 19 of the 29 items of the applied instrument. The loss of 10 items did not cause problems regarding the objective of the construct, maintaining an explained variance of 53.49\%, with reliability indices (TCDs $\alpha=0.89$ and BCDs $\alpha=0.90$ ). In addition, the CFA results confirmed the 2 -factor structure (performance by TCs and performance by BCs). Since the correlation between the factors was greater than 0.60 , it was possible to test a model with a second order factor (Roussel et al., 2002), which contains the dependent dimension to be measured, that is, the professional performance by competences in an integrated manner.

The CFA indices of the second-order model were satisfactory, ensuring the adequacy and reliability of the instrument (measured by Jöreskog's Rho). The ECPP showed convergent and discriminant validity for the used sample.

In this sense, it is trusted that this study offers an important contribution to the theme by providing the Brazilian context with a specific instrument to measure professional competencies in the police, filling a gap in Brazilian studies on competencies in the gendarme police sector. The importance of this study is reinforced by providing a scale of simple application, which can be used in combination with other organizational behavior variables to verify the antecedent and consequences of competencies (Nascimento, 2014; Nascimento \& Souza, 2017).

It is important to note that professional competences represent work performance itself, which starts from a robust theoretical conception (Durand, 2000; Gonczi, 1999; Santos, 2018). Such measures are scarce in Brazilian literature (Brandão et al., 2012a; Coelho et al., 2017; Santos, 2018), which makes it useful and appropriate (Nascimento, 2014) for future studies in the work context as a way to the improve precision and generality, in terms of external validity of the ECPP.

The results of this study demonstrated that the scale proved to be faithful to the objective and can be used by other police institutions as a way of assessing competences at work, thus presenting itself as an important management tool. In addition, the scale can be used for the elaboration and permanent redesign of strategic and tactical planning of organizations, for the achievement of management policies and practices, with emphasis on the organizational structure.

This study can contribute to the performance evaluation, focused on competencies, whose emphasis serves as support for planning work and organizing its activities, as well as serving as input for conducting training and development activities based on the survey of identified competence gaps (Faiad et al., 2012; Glória et al., 2014; Nascimento, 2014).

In addition, this research is part of the list of studies that seek a better understanding of professional competence measures, reflecting professional performance at work, especially in the public sector. Therefore, competence descriptions are fundamental for the adaptation and validity of work routines, allowing the diagnosis of competence gaps, as well as the proposition of interventions that lead to the elimination of these gaps.

Thus, ECPP can be used as a variable (dependent) in combination with other variables (antecedents) of organizational behavior, such as professional identity (Nascimento \& Souza, 2017), learning (Brandão et al., 2012a), support (Brandão et al., 2012b; Fogaça et al., 2018). This enables human behavior analyzes, based on more complex models involving several variables of interest to social science researchers.

The first theoretical contribution of this research was to present empirical evidences for the assumptions established by administration and psychology theories, regarding the understanding 
of professional competences (technical and behavioral) as an expression of work performance, improving organizational practices. In a particular and practical way, the managerial implications for PMDF are diverse. Its results may facilitate the planning of organizational interventions, beyond those already reported, which aim, for example, at inducing and using certain learning strategies at work and improving certain aspects of organizational support (Coelho, 2009; Fogaça et al., 2018). These operations would aim to increase the optimization regarding the development and expression of competences, resulting in better performance of the individual and, consequently, of the organization.

As potential limitations of the performed study, it is noteworthy that the samples were of convenience (not probabilistic), which entails the need for replication in other samples, as a way of verifying its stability (e.g., the presence of two discriminated factors). It is important to highlight the need to perform a nomological analysis of the ECPP, as well as a predictive analysis or even test its temporal stability (test/retest).

It is recommended, as a research agenda, to test the items indicated in the limitations, as well as associating ECPP to other variables of organizational behavior, antecedents (e.g., practices, organizational values, identities, learning) or consequences (performance and satisfaction) or moderators/mediators. Finally, ECPP is expected to provide a diagnosis of the TCs and BCs of different police officers and can be used for intervention purposes to implement management policies and practices focused on learning, that impact on the police organization.

Thus, we propose that new studies be conducted to verify new evidence of validity, generality and reliability, in Brazilian and foreign police organizations. Also allowing to update and revise these competences over time. In summary, it is imperative to reaffirm the importance of new competence mapping studies and the testing of new instruments in unexploited sectors of the public administration. 


\section{REFERENCES}

Abbad, G., \& Borges-Andrade, J. E. (2004). Aprendizagem humana em organizações de trabalho. In J. C. Zanelli, J. E. Borges-Andrade, \& A. V. B. Bastos (Orgs.), Psicologia, organizações e trabalho no Brasil (pp. 237-275). Porto Alegre, RS: Artmed.

Aguilar-Moya, R., Melero-Fuentes, D., AleixandreBenavent, R., \& Valderrama-Zurián, J.-C. (2013). Production and scientific collaboration in police training (1987-2011). Policing: An International Journal of Police Strategies \& Management, 36(4), 768-786.

Bäck, T., Vallès, L., \& Padyab, M. (2017). Police students' perceptions of professional competences: a comparative study of Catalonia and Sweden, Police Practice and Research, 18(5), 478-491.

Bagozzi, R. P., \& Yi, Y. (1988). On the evaluation of structural equation models. Journal of the Academy of Marketing Science, 16(1), 74-94.

Bitencourt, C. C., \& Barbosa, A. C. Q. (2004). A gestão de competências. In C. C. Bitencourt (Org.), Gestão contemporânea de pessoas: novas práticas, conceitos tradicionais (pp. 239-264). Porto Alegre, RS: Bookman.

Brandão, H. P. (2009). Aprendizagem, contexto, competência e desempenho: um estudo multinível (Doctoral Dissertation). Brasília, DF: Universidade de Brasília.

Brandão, H. P. (2017). Mapeamento de competências: métodos, técnicas e aplicações em gestão de pessoas (2a ed.). São Paulo, SP: Atlas.

Brandão, H. P., \& Bahry, C. P. (2005). Gestão por competências: métodos e técnicas para mapeamento de competências. Revista do Serviço Público, 56(2), 179-194.

Brandão, H. P., \& Andrade, J. E. B. (2007). Causas e efeitos da expressão de competências no trabalho: para entender melhor a noção de competência. Revista de Administração Mackenzie, $8(3), 32-49$.

Brandão, H. P., \& Guimarães, T. A. (2001). Gestão de competências e gestão de desempenho: tecnologias distintas ou instrumentos de um mesmo constructo? Revista de Administração de Empresas, 41(1), 8-15.

Brandão, H. P., Borges-Andrade, J. E., \& Guimarães, T. A. (2012a). Desempenho organizacional e suas relações com competências gerenciais, suporte organizacional e treinamento. Revista de Administração USP, 47, 523-539.

Brandão, H. P., Borges-Andrade, J. E., PuentePalacios, K. E., \& Laros, J. A. (2012b). Relationships between learning, context and competency: a multilevel study. Brazilian Administration Review, 9(1), 1-22.

Caetano, P. F. (2007). Construção e validação do inventário de competências pessoais para o trabalho - ICPT (Master Thesis). Brasília, DF: Universidade de Brasília.

Carbone, P. P., Brandão, H. P., Leite, J. B. D., \& Vilhena, R. M. P. (2005). Gestão por competências e gestão do conhecimento. Rio de Janeiro, RJ: Ed. FGV.

Coelho, F. A., Jr. (2009). Suporte à aprendizagem, satisfação no trabalho e desempenho: um estudo multinível (Doctoral Dissertation). Brasília, DF: Universidade de Brasília.

Coelho, F. A., Jr., \& Borges-Andrade, J. E. (2011a). Efeitos de variáveis individuais e contextuais sobre desempenho individual no trabalho. Estudos de Psicologia (Natal), 16(2), 111-120.

Coelho, F. A., Jr., \& Borges-Andrade, J. E. (2011b). Discussão sobre algumas contribuições da modelagem multinível para a investigação de desempenho no trabalho. Psico-USF, 16(2), 135-142.

Coelho, F. A., Jr., Rodrigues, D. A., Fogaça, N., Teixeira, J. A., \& Richter, L. D. D. (2017). Empirical relationships between support to informal learning, professional competences and human performance in a Brazilian public organisation. International Journal of Learning and Intellectual Capital, 14, 90-108.

Constituição da República Federativa do Brasil, de 5 de outubro de 1988. (1988). Brasília, DF.

Cordeiro, B. M. P., \& Muniz, J. O. (2010). Mapeando competências rumo à aprendizagem continuada em segurança pública. In: E. A. Pereira Junior, J. F. Silva \& J. Maron. (Org.), Um Toque de Qualidade. 
Eficiência e Qualidade na Gestão do Sistema de Defesa Social (pp. 103-125). Belo Horizonte, MG: Gráfica Andorinha e Editora Ltda.

Damásio, B. F. (2012). Uso da análise fatorial exploratória em psicologia. Avaliação Psicológica, 11(2), 213-228.

Decreto $n$. 5.707, de 23 de fevereiro de 2006. (2006). Institui a Política e as Diretrizes para o Desenvolvimento de Pessoal da administração pública federal direta, autárquica e fundacional, e regulamenta dispositivos da Lei n. 8.112, de 11 de dezembro de 1990. Brasília, DF.

Durand, T. (2000). Lalchimie de la compétence. Revue Française de Gestion, 127, 84-102.

Dutra, J. S. (2004). Competências: conceitos e instrumentos para a gestão de pessoas na empresa moderna. São Paulo, SP: Atlas.

Faiad, C., Coelho, F. A., Jr., Caetano, P. F., \& Albuquerque, A. S. (2012). Análise profissiográfica e mapeamento de competências nas instituições de segurança pública. Psicologia: Ciência e Profissão, 32, 388-403.

Fogaça, N., Rego, M. C. B., Melo, M. C. C., Armond, L. P., \& Coelho, F. A., Jr. (2018). Job performance analysis: scientific studies in the main journals of management and psychology from 2006 to 2015. Performance Improvement Quarterly, 30, 231-247.

Gilbert, T. F. (1978). Human competence: engineering worthy performance. New York, NY: McGraw-Hill.

Glória, O. S., Jr., Zouain, D. M., \& Almeida, G. O. (2014). Competências e habilidades relevantes para um chefe de unidade descentralizada de perícia da Polícia Federal. Revista de Administração Mackenzie, 15(4), 15-46.

Gonczi, A. (1999). Competency-based learning: a dubious past - an assured future? In D. Boud \& J. Garrick (Orgs.), Understanding learning at work (pp. 180-194). London, England: Routledge.

Jöreskog, K. G. (1971). Statistical analysis of sets of congeneric tests. Psychometrika, 36(4), 109-133.

Laros, J. A. (2012). O uso da análise fatorial: algumas diretrizes para pesquisadores. In L. Pasquali (Ed.), Análise fatorial para pesquisadores (Vol. 1, pp. 141160). Brasília, DF: LabPAM.
Le Boterf, G. (1999). Competénce et navigation profissionnelle. Paris, France: Éd. d'Organisation.

Lei n. 12.086, de 6 de novembro de 2009. (2009). Dispõe sobre os militares da Polícia Militar do Distrito Federal e do Corpo de Bombeiros Militar do Distrito Federal; altera as Leis ns. 6.450, de 14 de outubro de 1977, 7.289, de 18 de dezembro de 1984, 7.479, de 2 de junho de 1986, 8.255, de 20 de novembro de 1991, e 10.486, de 4 de julho de 2002; revoga as Leis ns. 6.302, de 15 de dezembro de 1975, 6.645, de 14 de maio de 1979, 7.491, de 13 de junho de 1986, 7.687, de 13 de dezembro de 1988, 7.851, de 23 de outubro de 1989, 8.204, de 8 de julho de 1991, 8.258, de 6 de dezembro de 1991, 9.054, de 29 de maio de 1995, e 9.237, de 22 de dezembro de 1995; revoga dispositivos das Leis ns. 7.457, de 9 de abril de 1986, 9.713, de 25 de novembro de 1998, e 11.134, de 15 de julho de 2005; e dá outras providências. Brasília, DF.

MacCallum, R. C. (1986). Specification searches in covariance structure modeling. Psychological Bulletin, 100(1), 107-120.

Malhotra, N. K., Kim, S. S., \& Patil, A. (2006). Common method variance in IS research: a comparison of alternative approaches and a reanalysis of past research. Management Science, 52(12), 1865-1883.

Marion, N. (1998). Police academy training: are we teaching recruits what they need to know? Policing: An International Journal, 21(1), 54-79.

Marôco, J. (2011). Análise estatística com o SPSS Statistics (5a ed.). Pero Pinheiro, Portugal: ReportNumber.

Marôco, J. (2014). Análise de equações estruturais: fundamentos teóricos, software e aplicações (2a ed.). Pero Pinheiro, Portugal: ReportNumber.

McClelland, D. C. (1973). Testing for competence rather than intelligence. American Psychologist, 28(1), 1-14.

McLagan, P. A. (1997). Competencies: the next generation. Training \& Development, 51(5), 40-47.

Morrison, G., \& Vila, B. (1998). Police handgun qualification: practical measure or aimless activity? Policing: An International Journal, 21(3), 510-533. 
Muniz, J. O., \& Proença, D., Jr. (2014). Mandato policial. In R. S. Lima, J. L. Ratton, \& R. Azevedo (Orgs.), Crime, polícia e Justiça no Brasil (Vol. 1, pp. 491-502). São Paulo, SP: Contexto.

Nascimento, T. G. (2014). Desempenho profissional: relações com valores, práticas e identidade no serviço policial (Doctoral Dissertation). Brasília, DF: Universidade de Brasília.

Nascimento, T. G., \& Souza, E. C. L. (2017). Escala Tri-Fatorial da Identidade Social (ETIS): evidências de sua adequação psicométrica. Psico-USF, 22(2), 217-234.

Nisembaum, H. (2000). A competência essencial. São Paulo, SP: Infinito.

Pasquali, L. (2010). Testes referentes a construto: teoria e modelo de construção. In L. Pasquali (Org.), Instrumentação psicológica: fundamentos e práticas (pp. 165-198). Porto Alegre, RS: Artmed.

Pasquali, L. (2012). Análise fatorial para pesquisadores. Brasília, DF: LabPAM.

Pasquali, L., Moura, C. F., \& Freitas, L. C. O. (2010). Análise profissiográfica. In L. Pasquali, (Org.), Instrumentação psicológica: fundamentos e práticas (pp. 441-454). Porto Alegre, RS: Artmed.

Portaria n. 208, de 25 de julho de 2006. (2006). Regulamenta o Decreto n. 5.707, de 23 de fevereiro de 2006, no que diz respeito à elaboração do Plano Anual de Capacitação e Relatório Anual de Capacitação. Brasília, DF.

Rodrigues, L. G., Nascimento, T. G., \& Neiva, E. R. (2014). Valores organizacionais e atitudes frente à mudança: o caso da Polícia Militar do Distrito Federal. Psicologia: Ciência e Profissão, 34(3), 574-591.

Roussel, P., Durrieu, F., Campoy, E., C., \& Akremi, A. E. (2002). Méthodes d'équations structurelles: recherche et applications en gestion. Paris, France: Economica.

Ruas, R., Ghedine, T., Dutra, J. S., Becker, G. V., \& Dias, G. B. (2005). O conceito de competência de A a Z: análise e revisão nas principais publicações nacionais entre 2000 e 2004. In Anais do 29o Encontro da Associação Nacional de Pós-Graduação e Pesquisa em Administração. Brasília, DF.

Santos, A. P. (2012). Competências, carreiras e contexto: um estudo multinivel na administração pública brasileira (Doctoral Dissertation). Brasília, DF: Universidade de Brasília.

Santos, A. P. (2014). Competência para a carreira de gestores governamentais; desenvolvimento e evidências de validade de uma escala. Revista de Gestão USP, 21(1), 27-41.

Santos, A. P. (2018). Escala de competências para os analistas em tecnologia da informação (ATI): desenvolvimento e evidências de validade. Revista do Serviço Público, 69(2), 145-162.

Secretaria Nacional de Segurança Pública. (2012). Perfil dos cargos das instituições estaduais de segurança pública: estudo profissiográfico e mapeamento de competências. Brasília, DF: Ministério da Justiça.

Veiga, C. C. P. S., \& Souza, J. S. (2018). A Produção Científica Sobre Formação dos Policiais Militares no Brasil. Revista Brasileira de Segurança Pública, 12(1), 50-70, 2018.

Yang, L.-R., Yen, H.-F., \& Chiang, Y.-F. (2012). A framework for assessing impacts of leadership competency on police project performance: mediating role of job satisfaction and moderating role of project type. Policing: An International Journal of Police Strategies \& Management, 35(3), 528-550.

Zarifian, P. (1999). Objectif compétence: pour une nouvelle logique. Paris, France: Liaisons. 


\section{Thiago Gomes Nascimento}

https://orcid.org/0000-0002-2432-3117

$\mathrm{PhD}$ in Management Sciences from the University of Aix-Marseille, France; PhD in Business Administration from the University of Brasilia; Coordinator and Professor of the Professional Master's Program in Strategic Management of Organizations at the IESB University Center. E-mail: thiago.nascimento@iesb.br

\section{Eda Castro Lucas de Souza}

https://orcid.org/0000-0002-8557-0592

$\mathrm{PhD}$ in Sociology from the University of Brasilia; Professor of the Professional Master's Program in Strategic Management of Organizations at the IESB University Center. E-mail: eda.lucas@iesb.br

\section{Breno Giovanni Adaid-Castro}

iD

https://orcid.org/0000-0002-9856-4263

$\mathrm{PhD}$ in Business Administration from the University of Brasilia; Professor of the Professional Master's Program in Strategic Management of Organizations at the IESB University Center. E-mail: breno.castro@iesb.br 